\title{
Does the quality of interlingual translation influence the quality of the intersemiotic translation? On the English language film adaptations of S. Lem's The Futurological Congress and Solaris in the light of their translations into English.
}

\author{
Agnieszka Majcher \\ Uniwersytet Jana Kochanowskiego, Poland \\ agamajcher74@gmail.com
}

\begin{abstract}
The aim of this paper is to compare two English language film adaptations (by Steven Soderbergh and Ari Folman) with each other and with the books they are based on. Stanisław Lem's novels - The Futurological Congress and Solaris - were translated into English and the directors of the films mentioned above were able to work with them. However, while one translation was appreciated by many, including the author of the original, the other one did not get much credit and features many inaccuracies, which will be presented below. The question of how much the quality of translation influences the intersemiotic translation, which adaptation is believed to be, will be examined in the paper. As, according to translation scholars, preliminary interpretation is vital for any translations, it seems justified to state that without being able to refer to the author's original thoughts the film-makers cannot produce a good adaptation. This will be revised on the basis of comparing examples from the books and films. The analysis will be drawn on an account of translation and film adaptation theories together with the outlining of cultural background for each work.

Keywords

interlingual translation, intersemiotic translation, film adaptation, science-fiction, Stanisław Lem, literary translation

\section{Introduction}

The aim of this paper is to consider potential relations between the quality of interlingual translation and inspired by it intersemiotic translation, which, according to some film researchers, a film adaptation is believed to be. In this article, the two English-speaking film adaptations ${ }^{1}$ based on the English translations of Stanisław Lem's prosaic works, i.e. Solaris (Lem, 2013a) and The Futurological Congress (Lem, 2014), will be analysed in the light of these translations and their correspondence with the messages of the original works in Polish. Also, the question if weaknesses of literary translations may in any way deteriorate the quality of the film referring to the book will be raised. Finally, having taken that a film adaptation is a kind of translation it will be investigated if one can impose the same requirements concerning film adaptations and literary translations and whether following the rules of how to create a good literary translation can be helpful while transferring a book onto a screen. Being aware that the proposed material is partial, which does not allow to constitute firm evidence for the hypothesis, one is, nevertheless, tempted to assume that, even though it is possible for a weak book to be a base for a good film, it is more likely for a well-translated book - in this case it means a literary piece the message of which reflects the one conveyed by the author of the original book - to be an inspiration for a good moving picture. It becomes an especially interesting issue to research, knowing we are able to study the
\end{abstract}

\footnotetext{
1 "Solaris" directed by Steven Sordenbergh from 2002 and "The Congres" by Ari Folman from 2013.
} 
book of letters Lem (Lem, 2013b) sent to Michael Kandel, the translator of The Futurological Congress (Lem, 1985), the letters that cover the thorough transfer of the author's ideas into a foreign language. On the other hand, a researcher can assume that such transfer must have been disrupted in the case of Solaris (Lem, 2003), as its English version was translated from another - French, translation and with no reference to Lem's suggestions. Thus, during such study one can observe if the ideas produced in Poland of the 1960s and the 1970s can be similarly expressed by the authors creating in the world of the West and whether it can be in any way helpful to make a film several decades later, presenting messages no less important than the original ones.

In this paper, first, the outline of the history of translation will be presented, pointing out what is important in the most recent approach to it. The next part will cover the issue of film adaptation as an intersemiotic translation. In the analytical part the transfer of ideas from the original books into the films will be looked into, in the light of Translation Studies review of selected examples from the English versions of the books conducted to assess the general quality of the translation, as well as with references to the reception of the films.

\section{From the theories of translation}

Translation has been defined in various ways. With regard to the type of the code, Jakobson (1989) distinguishes three ways of interpreting verbal signs. Intralingual translation, that is rewording, occurs when verbal signs are interpreted with other verbal signs of the same language. Interlingual translation, translation proper, interprets verbal signs from one language using verbal signs of another one. Intersemiotic translation, or so-called, transmutation, makes use of non-verbal system of signs to interpret verbal signs. Nevertheless, within the last two millennia there have appeared a number of definitions and attempts to approach the issue.

The differences come from a variety of translated materials, goals of the translations, their recipients' needs and different philosophical views of translators. One of the proposed definitions by Nida and Taber (1982) states that translation is constituted by reproducing in the recipient's language the closest natural equivalent of the source language message, both in terms of meaning and style. Other approaches aim at producing the text in the target language which has an intended or required function in this language. Several oppositions describing the properties of translation can be vital: literal - free, literary - non-literary, semantic - communicative, form - content. In the study of style one must also consider philological theories of translation. According to Nida (2001), being the extension of philological approach to literary analysis, they investigate corresponding written texts in the source and the target language, trying to evaluate their equivalence, dealing with structures, stylistic and rhetorical devices, the literary genre and cultural influences.

Steiner (2000) in his study on translation identifies four periods in its history. The first one, starting in Ancient Rome, lasted until the Enlightenment. It features an empirical approach, encompasses first attempts to organize the issues of translation, starting from the question: word for word or sense for sense. The second period, finished in the 1940s, was more theoretical and its nature was more hermeneutical. Those days, the questions about translation merged with questions about a language and state of mind. Started by Schleiermacher, continued by Schlegel and Humboldt, hermeneutics tried to answer the question what it means to understand the text. The questions concerning translation were raised in philosophical aspects. The third period takes us into modernity. There appear first works on machine translation. Formalists use linguistic theories and statistics to study literature and translation. There appear models of connections between formal logic and linguistic transfer. Structural linguistics enters the discussion concerning interlingual exchange. Organizations comprising professional translators are set up.

The third phase has practically been still on, yet, some changes that took place in the 1960s made Steiner (2000) distinguish the fourth period, initialized by the discovery of the work by Benjamin from 1923 - "The Task of the Translator". This text, along with the great influence from Heidegger and Gadamer, made translators and translation scholars return to hermeneutics and ask almost 
metaphysical questions of the essence of translation and interpretation. Again there appeared enquiries into universalist or relativist character of a language. Translation has become a subject of study by psychologists, anthropologists, sociologists. Humboldt's conviction that each act of communication is a translation has become valid again.

Steiner (2000) emphasizes that human speech consists of arbitrarily chosen, but considerably conventionalized signs, the meaning of which can never be separated from the form used to express it. There are no transparent places in a language, however transparent the style seems to be. Each reading is translation, and each deliberate translation, intralingual, interlingual or intersemiotic, requires preliminary interpretation. As Balcerzan (1998) points out, in the literary translation a significant deal of the work should be attributed to the translator.

One does not need scientific evidence to state that much of the film adaptation comes from its director and that film language also uses conventionalized signs, though they are not so codified and are more prone to mutations than human speech. Therefore, the assumption that while transferring a book onto a screen we cope with the problems parallel to those faced while translating a piece of literature. And also, that a recipient of both types of translation is likely to meet similar obstacles while interpreting the target materials.

\section{Film adaptation as intersemiotic translation}

The theoretical part presented below is fully based on the study by Choczaj (2011). According to her, adaptation has been analysed in many structural-semiotic ways, considering the category of equivalence of signs in translation, making use of such terms as transformation, transposition, transcription, or intersemiotic translation. Among those who were in favour of granting film adaptation the label of intersemiotic translation were Eichenbaum (cf. Choczaj, 2011), Münsterberg (cf. Choczaj, 2011), Orłowski (cf. Choczaj, 2011) (who postulates the existence of the system of language signs transposition into the system of audiovisual signs, based on finding equivalence between works of various structures), Hopfinger (cf. Choczaj, 2011) (pointing out, however, that full translation is impossible due to lack of equivalence of the systems). The latter recognizes adaptation as a kind of reading-interpretation of the literary input material which must be the result of numerous external factors such as development of filming techniques as semiotic system. Laskowicz (cf. Choczaj, 2011) dubbed interpretation a kind of transformation in the semiotic and sociological context. She acknowledged that system differences between the film art of many fabrics and the literature of one fabric mean that adaptation always deforms its original, as it is only multiplied and subjective transformation. While Bettetini (cf. Choczaj, 2011) claimed that transcription is unlikely to be achieved, and neither is thorough translation, Osadnik (cf. Choczaj, 2011) revives the transformative approach towards adaptation. According to him, each work of film art (target text) is an adaptation of a literary work (source text) - that is a screenplay. What is to be assessed is equivalence, not adequacy, as the measure of such translation is not faithfulness but approval. Osadnik understands translation as a process dealing with cultural, social and moral contexts.

What one may find interesting is that, despite current opposition (e.g. represented by the popular theory of adaptation as "creative betrayal" by Helman (cf. Choczaj, 2011)), semiotic research concerning adaptation has not disappeared, yet has been subject to transformation. Wysłouch (cf. Choczaj, 2011) revives the postulate of intersemiotic translation emphasizing correspondence of arts. In her theory, the term of transcription, along with transliteration, description and borrowing, returns as one of the four translating principles. This allows to transfer a phenomenon from one system to a different one, for instance from literature to film. Thanks to relatedness of film and literary signs, the systems are translatable. Finally, Spedicato (cf. Choczaj, 2011) refers to interlingual translation, mentioning Translation Studies model by Malone for the first time in the film sciences context.

Although, as Choczaj (2011) states, in studies concerning adaptation one can observe significant dominance of literary studies approach, where literary work is regarded as the original and the value of adaptation is evaluated according to its dependability on the literary piece or its autonomy, taking film 
adaptation as an intersemiotic translation is fully justified as thus film adaptation will be treated in the further part of this paper.

\section{Analysis}

While analysing works of art that use different "fabric", as it is in the case of books in different languages and, moreover, films, one must carefully trace the transfer of the ideas from the original books, through their translations, and to the adaptations. Without an attempt to grasp the main message of the original book (in the light of the theories mentioned above) one cannot assess the value of any translation, interlingual or intersemiotic. To state if the general quality of the translation proper has been achieved, it is advisable to refer to some selected examples from the English versions of the books in terms of translation analysis. The combination of these steps can help us draw the conclusion whether, despite some obvious differences between the book and the film, the links between the quality of translation and film adaptation can be observed.

Lem's Solaris (2013a), written in 1961, is a story of a scientist, Kris Kelvin, who, having arrived in research space station in the vicinity of the planet Solaris, experiences inexplicable encounters with a walking embodiment of the memories of his long-dead wife. The creature, which is not subject to any laws of earthly physics, seems to be the product of the Solaris's ocean. The ocean has been categorized as a living and thinking creature and the doppelgangers it produces appear to be the climax of the attempts to make contact between the ocean and people. Sadly, as the reader can see in the course of action, the greater lengths we go to so that the contact and understanding can be established, the further we get from it. Such conclusion can be also drawn from the tons of scientific volumes presented in the book. The presumed gifts from Solaris turn out to be a curse and rich terminology used to describe the ocean only makes the image more obscure. (Is it not the trouble with contemporary earthly science?)

The incapability of contact is symbolically expressed in the last scene, where Kris reaches the plasma of the ocean with his hand and it smothers the limb, making a kind of a negative, a cast of it, flexible but distant, as there is always some space in spite of the movement. The lack of direct contact can be post factum interpreted as an allegory of the condition of translations and interpretations of this work neither the literary translation from 1970 (Lem, 2003) nor the adaptation by Steven Soderbergh are among works unequivocally praised. "The New York Times" (Holden, 2002) in its review writes that the result of co-operation between Soderbergh and Cameron is getting rid of many disturbing scientific and philosophical details, turning the story into a popular fairy tale, without bothering the audience with linking the meanings, and exchanging the intellectual values of "Space Odyssey" for romantic framing like one of the "Titanic". The conclusion - balancing on the verge of two genres was not successful.

It is hard not to agree. The reception of the film in Poland is even more ambivalent. Turning our flagship proposal of science-fiction literature into a metaphysical story of the second, third, or even fourth chance in love is disappointing. One cannot help noticing that the actors themselves seem confused. Is it possible that reducing the philosophical aspects of the novel could have been caused by its insufficient understanding resulting from the flaws of the translation? This cannot be ruled out. Ironically, although in the West Solaris is regarded as Lem's showcase work, until 2011 it did not have a satisfactory translation (cf. Lem, 2011). The translation by Kilmartin \& Cox (Lem, 2003) was prepared on the basis of the French translation. The result of this multiplied copying is a lot of inconsistence on various levels of language. Some errors refer to proper names. Although all spaceships in Solaris bear the names of mythological heroes, one of them, Laokoon in the original [Laocoön]2, is recalled in the English version as Laakon. One cannot also find firm excuses that made the authors of the 1970 translation change the first names or surnames of the people inhabiting the international station and call Snaut - Snow, and Harey - with its anagram Rheya (these names appear in the film adaptation). While the former change can be explained by the urge to use a more conventional and devoid of

${ }^{2}$ All translations and explanations in square brackets were made by the author of this paper. 
unnecessary associations English name, the latter is strange. Why has the perfectly English name been changed so that is has the characteristic Slavic suffix "a"? Another issue is obscuring the message in the translation. As a result of proximity of the "guests", the scientists want to keep their conclusions secret and decide to call them in the original text fantomy - twory $F$ for short. Kilmartin \& Cox copy the name, using phantom in their translation (cf. Lem, 2003). That would be perfect if they had not decided to use Phi-creatures as the alias for them. Thus, instead of a quite neutral letter of the Latin alphabet, the reader is given the Greek phi, burdened with quite vast meaningfulness, of which the mathematical symbol of circumference is the easiest example. This can significantly influence the interpretation, especially when the readers will allow themselves for global intertextuality play. ${ }^{3}$

The translation features complex sentences and groups of sentences devoid of sense or with an illogical meaning. While the original says: “Giese jednak, który we wszystkich opisach innych stworów solarycznych zachowuje się jak mrówka, chodząca po zamarzłym wodospadzie, niczemu nie dając się wytrącić z miarowego kroku swej oschłej frazy, tak był pewny swego, że poszczególne fazy wyłaniania się mimoidu uszeregował w ciąg rosnącej doskonałości." [Giese, however, who in all descriptions of other Solaris's creations behaves like an ant crawling on a frozen waterfall, allowing nothing to distract him from the steady pace of his dry phrases, was so sure to be right that he put subsequent phases of a mimoid emerging in a sequence of increasing perfection.], the first translation will present: "Giese would not abandon his account of the various phases of the process as a sustained progression towards perfection, with a conviction which is particularly surprising coming from a man of such moderate, cautious turn of mind in advancing the most trivial hypothesis on the other creations of the ocean. Normally he had all the boldness of an ant crawling up a glacier."

To sum up, the language obscuring the reading of the target text calls for simplifications, including simplified interpretation, for drawing the most obvious and popular conclusions and keeping only them with the use of audiovisual code - for the sake of a less demanding audience.

Soderbergh's adaptation, apart from the abovementioned emphasis of the love theme, introduces more modifications. Sartorius becomes (in the name of general correctness?) a black woman, while the plump African woman produced in the book by one of the crew - Gibarian's mind turns out in the film to be his young son. Some themes that were barely suggested in the book become obvious in the film.

How far from the original book the adaptation based on it can be illustrated by the ending of the film. The film is devoid of the scene of Kris's landing on a mimoid (described above). What corresponds with it is the last but one scene in the film, when Kris, losing his vitality as a result of the ship getting closer to the planet, sees the boy - the Solaris's creature, representing the mind of the ocean. The boy reaches his hand towards Kris, their fingers meet in the pose well-known from the fresco in the Sistine Chapel, nevertheless so meaningless due to overexploitation of the image in popular culture. Compared to the profound and visually rich scene of "touching the ocean" in the book, preceded by a dialogue about the nature of gods, this mass-production image becomes symbolically sad. Instead of pondering on god's duality we are additionally offered a kind of a happy ending in the moving picture. Ironically enough, now Kris - George Clooney's sad countenance, expressing "why-am-I-here" question, encourages buying the book both in English-speaking countries and in Poland.

The state of interlingual and intersemiotic translations of The Futurological Congress (Lem, 2014) seems different. Written in 1970, the prose by Lem presents the adventures of Ijon Tichy, an astronaut, who after the political rebellion and its inconceivably strange consequences is taken from The Futurological Congress in Costaricana to New York of the future. Lem creates for his readers the vision of a utopian - anti-utopian world, where people, aware to some extent and to some by deceit, let powerful hallucinogenic pharmacological substances control over their lives. The drugs allow them to live in the illusion of blissfulness in the actually rotting world.

The tasks which the translator of this literary piece faces are multiple. First of all, the world depicted - Latin America and the United States, especially the States, must look credible for the English speaking

3 The latest translation deals much better with this: the creatures are called "ghosts", that is "G-formations". 
reader. All cultural hints conceived by Lem must face the reality of the actual country. Thus, word puns, neologisms must find their equivalents in the language of a different structure. Kandel did his job well (cf. Lem, 1985). Towarzystwo Opieki nad Robotami [Society of Taking Care of Robots] has been turned into Society for the Prevention of Cruelty to Automats, SPCA. This acronym, without any modification is the name of the popular organization looking after animals in the USA and the UK. The term Bemby, Bomby Miłości Bliźniego [Bombs of Loving Thy Neighbour] (BMB), has found its equivalent in LTN (Love Thy Neighbour) bombs, the name combining associations with the TNT explosive material and "Love thy neighbour" commandment from the Gospel.

In his letter to the translator, Lem (2013b) compliments him on surpassing the original, creating a purely American text, yet remaining faithful to the original.

Secondly, the American must realise that, while in the 1970s the Poles still saw the vision of imposed totalitarian happiness as a real thing, the threat of serious political changes in the West was not so clear as some decades before when the visions by Huxley and Orwell had stirred imagination for the first time. Therefore, it would be better to emphasize the message of The Futurological Congress as a warning against deformed overconsumption rather than as a hidden hint concerning political situation. Lem (2013b) himself in the letter to Kandel, pointing out it is wrong to facilitate in any way the reading comprehension for the English speaking reader, writes:

The Congress is a kind of a paraboly of consumptionist community, the community targeted at MASSFACILITATION as SUPERIOR VALUE of existence, and this targeting brings about a crisis of authentic values, those historically created, while 'psychemistry' is an ultimative and universal technology of smoothing the path. The final scene implies that the world was shaped differently, that a moment comes when instrumental hedonism must PAY for its practices, and the pay turns out rather nightmarish. ${ }^{4}$

Although the author admits later that his opinion concerning the interpretation of the book is not binding, one cannot help accepting this universal message, abandoning the one that has tempted the western readers, to regard the book as a voice from behind "the iron curtain" allegorically presenting the system in force. It would require further research to state whether the author of the English version was in favour of one of the interpretations and this is not the main goal of this article. However, one can read in the interview with Ari Folman, the director of The Congress that he was looking for a new, more contemporary expression for the allegory of communism included in the book (cf. INTERVIEW). As a result, he was forced to introduce significant changes to the plot. Amazingly, the changes led to producing the film whose message could be expressed with the words by Lem quoted above. The universal reading of the book proved right after decades.

In Cannes The Congress was dubbed the most anti-Hollywood movie ever made (cf. Kohn, 2013), yet it was much credited. This unusual production, half traditional with actors, half animated with the use of up-to-date motion capture method, is truly impressive. The review (Kohn, 2013) reveals phrases like: "genius design", "beguiling project," "stunning appearance and the extraordinary depth of insight", "beauty and wonder as vessels for rage". The production is said to "rail against commercialism".

The director himself, undoubtedly using Kandel's translation as his base ${ }^{5}$, tells us in the promotional materials about the need of courage that adapting a classic book requires; about how brave one must be to free from the text to some extent. Thus, he had to change political dictatorship into an entertainment industry dictatorship, especially emphasizing the overly control film studios have taken over our lives (cf. INTERVIEW). In such circumstances, replacing the astronaut Ijon Tichy with an ageing actress (Robin Wright playing herself) is more than justified. The new identity of the leading character leads to

\footnotetext{
${ }^{4}$ Translated by the author of this paper.

5 In the film, Kandel's neologisms appear, such as LTN bombs.
} 
further changes in the storyline (family theme, the idea of selling one's digital image to film producers, followed by the loss of identity).

What has been preserved from the book - the idea of willingly giving up the control over us to omnipotent psychotropic substances - or actually to their distributors, the idea of masking the dull reality with the illusion of wonderful worlds, the vision of people incapacitated under the appearances of being given happiness in a pill - these have not changed and after forty years speak volumes to the contemporary audience.

In the last scene of the book Lem, gracefully and ironically, releases the character from the nightmare, revealing that even the final phase - the world devoid of chemical boosters - was an illusion, hallucination created by overdose of psychotropic gas spread under the Hilton hotel in Costaricana. Robin Wright manages to get away from the vapour masking the decaying reality, returns from the animated to the real world here and now, but the changes that have taken place are irrevocable. The recipient from the $21^{\text {st }}$ century seems more pessimistic and apparently can face reality without the mask of irony...

\section{Conclusion}

To sum up, one cannot present a simple recipe on how to make a successful film adaptation. Studying the relations between the literary translation and the quality of its screen version will always meet counterarguments, like those saying that even good non-translated books happen to have weird and failed film adaptations. Nevertheless, if we take both literary translations and film adaptations as types of translations - interlingual and intersemiotic - we will observe a number of analogies. Undoubtedly, according to the abovementioned contemporary approach towards translation, it requires an appropriate series of preparatory activities, understanding the input material and having an opinion on it. The effort made at this stage may result in a piece of work that will be at least good. On the other hand, a series of not very successful interpretations or translations leads, like in Chinese whispers, to works less and less touching the original senses. And, even though these days few care for the author's opinion - the author of the original book in this context - each attempt of engaged reading of his intentions gives us the scope for a creation no worse than the original.

Therefore, The Congress, the film apparently more distant from Lem's book, has more in common with the message of the original than, seemingly quite faithful to the story in the printed version, but missing important points, "Solaris". And thus, imposing the same requirements (yet for different type of signs, of course) for film adaptations that usually refer to literary translations is fully justified and can be helpful when defining the features of a good film adaptation.

\section{References}

Balcerzan, E. (1998). Poetyka przekładu artystycznego. In Literatura z literatury (strategie tłumaczy), 17-31. Katowice: Śląsk.

Benjamin, W. (2012). Zadanie tłumacza. In A. Lipszyc (Ed.), Konstelacje, Wybór tekstów (pp. 23-36). Kraków: Wydawnictwo Uniwersytetu Jagiellońskiego.

Choczaj, M. (2011). 0 adaptacji, ekranizacji, przekładzie intersemiotycznym i innych zmartwieniach teorii literatury, filmu i mediów. Przestrzenie Teorii, 16, 11-39.

Holden, S. (2015, September 22). Their love will go on in outer space. The New York Times. Retrieved from http://www.nytimes.com/movie/review?res=9405E1DC1638F934A15752C1A9649C8B63

Jakobson, R. (1989). 0 językoznawczych aspektach przekładu. In M. R. Mayenowa (Ed.), W poszukiwaniu istoty języka, vol. 1 (pp. 372-381). Warszawa: Państwowy Instytut Wydawniczy.

Kohn, E. (2013, May 17). Cannes: is Ari Folman's 'The Congress' the most anti-Hollywood movie ever made? Indiewire. Retrieved from http://www.indiewire.com/article/cannes-is-ari-folmans-thecongress-the-most-anti-hollywood-movie-ever-made

Lem, S. (1985). The futurological congress: From the memoirs of Ijon Tichy. Tr. M. Kandel. New York: A Harvest Harcourt Inc. Book. 
Lem, S. (2003). Solaris. Tr. J. Kilmartin, S. Cox. London: Faber and Faber.

Lem, S. (2011). Solaris. Tr. B. Johnston. Kindle Edition, Premier Digital Publishing.

Lem, S. (2013a). Solaris. Kraków: Wydawnictwo Literackie.

Lem, S. (2013b). Sława i fortuna, Listy Stanisława Lema do Michaela Kandla 1972-1987. Kraków: Wydawnictwo Literackie.

Lem, S. (2014). Kongres Futurologiczny ze wspomnień Ijona Tichego. Kraków: Wydawnictwo Literackie. Nida, E. A. \& Taber, Ch. R. (1982). The Theory and Practice of Translation. Leiden: Brill.

Nida, E. A. (2001). Contexts in translating. Amsterdam, Philadelphia: John Benjamin's Publishing Company.

Steiner, G. (2000). Po wieży Babel. Problemy języka i przekładu. Kraków: Universitas.

Folman, A. (Interviewee). Interview with Ari Folman. Retrieved from http://thecongressmovie.com/behind-the-scenes-1.htm?lng=en

\section{Contact}

Agnieszka Majcher, MA

Os. Na Stoku 80/34

25-437 Kielce

Poland

agamajcher74@gmail.com 